\title{
Influence Of Socio-Psychological Characteristics In Adoption Of Organic Farming Practices In Coconut Based Homesteads In Humid Tropics
}

\author{
J. K. J. P. Jayawardana and ${ }^{1}$ A. K. Sherief \\ Coconut Research Institute, Lunuwila, Sri Lankal Kerala Agricultural University, Kerala, India.
}

\begin{abstract}
A study was conducted to find out the influence of socio-psychological characteristics in adoption of organic farming practices in coconut based homesteads. The study was conducted in Kalliyoor, Venganoor and Kuzhumilum panchayats of Nemom, Adiyanoor and Chirayin keezh blocks respectively in Thiruvananthapuram district in Kerala state, India. Multistage random sampling technique was administered to select 105 coconut based homesteads farmers, 35 per each block. Data were collected through pretested structured interview schedule and the relationship between the dependent variables and adoption was studied using correlation analysis. Correlation coefficient indicated that education, innovativeness, risk orientation, market perception, self confidence, information seeking behavior, awareness, knowledge and attitude towards organic farming practices showed significant correlation with adoption. However age, experience in coconut cultivation, livestock possession, training attended and environmental orientation had negative and non significant correlation with adoption of organic farming practices among the coconut based homestead farmers.
\end{abstract}

\section{INTRODUCTION}

Coconut enjoys a distinct place in the economy of the state of the Kerala, India. Coconut in Kerala is essentially a crop of small and marginal farmers. The average size of holding is only 0.2 ha and $98 \%$ of the holdings are below 0.2 ha. Nearly 2.5 million farmers are earning their livelihood directly or indirectly from coconut cultivation. Home garden agriculture is common in all the major agro ecological regions in Kerala, Its characteristic feature the predominance of homesteads and homesteads farming. A homestead is an operational unit in which a number of crops of which major crop is coconut are grown with livestock, poultry and fish, mainly for the purpose of satisfying the farmers basic needs. (Nair and Sreedharan, 1986).

Most of the coconut production comes from small and marginal farmers. Only limited percentages of farmers use chemical fertilizers 
and as a result vast majority of palms remain under fertilized or unfertilized (Nampoothiri, 2001). Continuous use of chemical fertilizers results in increased soil acidity, imbalance of major and micro nutrients and decrease in soil biological properties. The situation demands application of low cost organic nutrient sources which will help in improving the soil fertility and productivity. There is enormous potential in practicing organic farming in coconut based homesteads, as coconut palm itself produces huge amount of biomass for recycling (Singha, A. K. 1996). Adoption of any agricultural practice mainly depends on socio-psychological character of the farmers. The present study was conducted to find the socio-psychological characters which influence in the adoption of organic farming practices among the coconut based homestead farmers.

\section{MATERIALS AND METHODS}

The present study was conducted in the randomly selected panchayata of Kalliyoor, Venganoor and Kuzhimilum of Nemom, Adiyanoor and Chirayinkeezh blocks respectively in the Thiruvananthapuram district, Kerala. Multistage random sampling technique was administered to the identification of 105 coconut based homestead farmers. The data were collected with the help of pre tested structured interview schedule by personally interviewing the respondents. In order to examine the relationship and rate of dependence of adoption of organic farming practices upon the selected fourteen independent variables, simple correlation coefficient was tested by comparing with the table values.

\section{RESULTS AND DISCUSSION}

Table 1 : Relationship between the socio-psychological characters of coconut based homestead farmers and adoption or organic farming practices.

\begin{tabular}{|c|l|c|}
\hline $\begin{array}{r}\text { SI } \\
\text { No. }\end{array}$ & \multicolumn{1}{|c|}{ Independent variables } & $\begin{array}{c}\text { Correlation } \\
\text { coefficient }(\mathbf{r})\end{array}$ \\
\hline 1 & Age & 0.0995 \\
\hline 2 & Experience in coconut cultivation & 0.1167 \\
\hline 3 & Education & $0.4834^{* *}$ \\
\hline 4 & Livestock possession & 0.1179 \\
\hline 5 & Training attended & 0.0711 \\
\hline 6 & Innovativeness & $0.3717^{* *}$ \\
\hline 7 & Risk orientation & $0.2730^{* *}$ \\
\hline 8 & Market perception & $0.8952^{* *}$ \\
\hline 9 & Self confidence & $0.5256^{* *}$ \\
\hline 10 & Environmental orientation & 0.0747 \\
\hline 11 & Information seeking behavior & $0.4383^{* *}$ \\
\hline 12 & Awareness on organic farming practices & $0.3589^{* *}$ \\
\hline 13 & Knowledge on organic farming practices & $0.9468^{* *}$ \\
\hline 14 & Attitude towards organic farming practices & $0.5867^{* *}$ \\
\hline
\end{tabular}


Table1. shows that out of the 14 variables namely, education, innovativeness, risk orientation, market perception, self confidence, information, seeking behavior, awareness, knowledge and attitude had positive and significant correlation with adoption of organic farming practices.

The education had positive and significant correlation on adoption of organic farming practices. This might be because education helps an individual to acquire more knowledge, understand better and inclined to get correct information for use in farming.

The farmer's orientation towards scientific farming may increase due to education which leads them to achieve great production by adopting recent developed organic farming practices.

The innovativeness showed positive and significant correlation with adoption. Innovative farmers are always keen about their farming practices and progressive in outlook. Hence they tend to seek changes in their farming practices and eager to try or experiment new technologies in their own fields.

The correlation coefficient between risk orientation and adoption was found to be positive and significant. The farmer who is willing to take the risk in farming always tends to try out new technologies without hesitation. This might have been the reason for the above relation.

Market perception had positive and significant relationship with adoption. Having realized the market trend of produce, its demand and price etc, farmers tend to adopt organic farming practices. Hence market perception might have led to more adoption of organic farming practices.

It was noteworthy from the study that the self confidence had a positive and significant relationship with adoption. Self confidence makes farmers to develop ability to face risks. Self confidence level of farmers, determines the decisions for adopting organic farming practices. This might be the reason for a significant and positive relationship between self confidence and adoption.

The information seeking behavior had positive and significant relationship with adoption. Farmers can gather information through various information sources. Authentic information from reliable sources might have facilitated higher level of adoption.

The correlation coefficient between awareness and adoption was found to be positive and significant. With the increasing awareness farmers develop favorable attitude towards organic farming through their own experience which led to the higher level of adoption.

Knowledge is the prerequisite for adoption. Knowledge on organic farming practices had positive and significant relationship with their adoption. This might be because the respondents were having more knowledge are more conscious about the organic farming practices.

Attitude exhibits positive and significant correlation with adoption. High level of awareness and knowedge might have also contributed to the farmers to change their 
attitude. This means that farmers with positive attitude adopted more organic farming practices than the farmers with negative attitude.

Table 1. Shows that age, experience in coconut cultivation, livestock possession, training attended and environmental orientation were negatively and not significantly correlated with adoption.

\section{CONCLUSION}

In this study education, innovativeness, risk orientation, market perception, self confidence, information seeking behavior, awareness, knowledge and attitude towards organic farming practices were observed to be valuable socio-psychological variables with reference to adoption of organic farming in coconut based homesteads. Adoption of organic farming practices was not found to be up to the expected mark. Hence special attention needs to be given to encourage the adoption of organic farming practices. The efforts to increase the knowledge of farmers about organic farming practices will naturally help in the use of their practices. In addition to this special extension programme needs to be launched for sustainable adoption of organic farming practices in coconut based homesteads. Particularly the method and result oriented demonstrations on farmer's field will help to convince the farmers in the use of organic farming practices.

\section{REFERENCES}

Nair, M. A and Sreedharan, C. (1986). Agroforestry system in the homesteads of Agrof. Kerala, South India Agro Syst. 4: 339-363.

Nampoothiri, K. U. K. (2001). Organic farming - Its relevance to plantation crops. J. Plantation Crops. 29 (1) : 1-9.

Singha, A. K. (1996) Adoption pattern of coconut cultivation practices in a progressive area of Assam. J. Extn. Edu. 7 (1) 1314 - 1317) 